\title{
Brave New World: \\ Citizenship in Geospatially Enriched Environments
}

\author{
Sarah Witham Bednarz and Robert S. Bednarz \\ Texas A\&M University College Station, USA·s-bednarz@tamu.edu \\ Full paper double blind review
}

\begin{abstract}
Citizenship education has a long and varied history in the United States; geographers have played a relatively minor role in its development through the social studies. This paper reviews citizenship education, geography's contribution to it, and suggests ways geography educators can take a more vibrant and important role in this vital task through geospatial technologies, mapping, and spatial thinking.
\end{abstract}

\section{Introduction}

The explosive and concurrent growth of geospatial technologies and social media are changing how we live. As Downs (2014) makes clear, the ubiquity of GIS, Remote Sensing, GPS, and associated technologies, particularly mapping technologies, has affected the relationships people have with each other and the world in which they live. Enormous quantities of digital geographic data are available in real-time. We are monitored on closed circuit television systems; we check in to let friends know where we are through Facebook and Four Square; our smartphones track our physical activities and locations. We express our opinions on a range of issues frequently through Twitter, Instagram, and other sharing applications. We report on traffic patterns, complain about neighbors who do not pick up their garbage, and alert authorities about suspicious activities through place-oriented social media. Who we are, where we are, what we do, and how we feel is shared in geographic contexts. The world is at everyone's fingertips, all the time (Downs 2014). How does this brave new world affect us as members of society? How is it affecting our roles as citizens and at what scales? What are the challenges and opportunities for geographers in taking a leadership role in preparing the next generation of geospatially literate citizens?

This paper examines these issues in the context of the United States in the first decade of the 21st century, a time of uncertainty, disruption, and rapid change. As geography educators with a particular interest in spatial thinking and literacy, we begin by examining the role geography has traditionally played in citizenship education in the United States. Next we describe what geospatial technologies and spatial thinking can add to the development of educated and committed citizens. We conclude with recommendations based on collaboration with educators working to enhance instruction in spatial thinking, geospatial technologies, and citizenship education. 


\section{Citizenship in the 21st Century}

Conventional wisdom in the United States is that the terrorist attacks of September 11, 2001, (commonly referred to as "9/11") made citizenship education a national imperative. Certainly the event sparked debate about the nature of citizenship, the best ways to develop "good citizens," and the appropriate responsibility of schools and society in this endeavor. Since that cataclysmic event at the beginning of the century, we have been confronted with new and ongoing concerns related to climate change, terrorism, armed conflict, racial and ethnic animosities, and globalization in its many manifestations. While each generation perceives the times in which they live as uncertain, a convincing case can be made that we are living in a world with more uncertainty than ever before (BEDNARZ \& BEDNARZ 2008). Perceptions of vulnerability influence the way we view our society and our roles in it, in essence defining what it means to be a citizen. Some suggest that geospatial technologies (also known as geomedia) and geographic data can help us manage uncertainty. Certainly as outlined in the beginning of this paper, social media also can play a role in helping us cope with our uncertain world.

Relatively few U.S. geography educators have participated actively in discussions about citizenship, leaving geographers vulnerable to charges that they are not concerned about citizenship education, and that we are ignoring a significant educational issue (BEDNARZ \& ACHESON 2003). A lack of public engagement in formal discussions of citizenship does not necessarily mean that geography educators are not committed to civic education and to instilling in students civic virtues. Neither does it mean that geography has not contributed in this key arena. However, it is obvious to us that geography educators should examine how the affordances of geospatial technologies and social media can enrich citizenship education. But what is citizenship education in the United States today?

\section{Citizenship Education in the United States}

The notion of citizenship is important in the United States and has been throughout its history. Because of our pluralistic, immigrant society we have struggled with the issue of creating a unified national identity. One popular approach to achieving this goal has been to enlist public education. The creation of an informed citizenry, able to participate in democratic institutions, has always been a primary goal of America's schools (THORNTON 2004). At the beginning of the 20th century, when immigration was at an all-time high, the stated purpose for the social studies (of which geography is a part) was to promote patriotism and citizenship in order to assimilate newcomers into "American" society (MURPHY 2002). This concern has persisted to the present day leading to a parochial view of citizenship focused solely on national identity and patriotism (MYERS 2006).

As interest in citizenship has grown, concern about young Americans' understanding of core ideas and principles related to civics has arisen. The 2014 National Assessment of Education Progress (NAEP) in Civics revealed disturbing gaps in students' civic knowledge. Students in Grade 8 (roughly 14 years old) improved performance between the first administration of the test in 1998 and 2010 but showed no significant change between 2010 and 2014. Only 23 percent of students performed at or above the proficient level, that is, were judged competent over the subject matter. The majority of students were not able to 
identify a belief shared by most people in the U.S., interpret a graph about voting behavior, or explain the benefits of international interactions (NAEP 2015).

A report from the Center for Information and Research on Civic Learning and Engagement (CIRCLE) found that 57 percent of 15 to 25 year olds are completely disengaged from civic life (KEETER et al. 2002). This followed the enormously influential work of Robert PUTNAM (2000), the political scientist who chronicled the decline of civic engagement by identifying ways in which U.S. residents have withdrawn from normal forms of social interaction. It is widely accepted by many political and education leaders that the public schools have failed to promote students' citizenship skills and behaviors; traditional methods of civics education are not preparing students adequately (RUBIN 2015). The events of 9/11 and the uncertainty highlighted previously have magnified these concerns. Research indicates that young adults are now less likely to be involved in community activities such as belonging to a group, reading newspapers, working on community projects, or affiliating with a political party (FLANAGAN \& LEVINE 2010). Only volunteering is on the rise, largely through school schemes emphasizing service learning (PARKER 2014).

While citizenship is perceived as important and worthy of attention and promotion, it is not well-defined. Among other things, citizenship denotes the enjoyment of rights, active participation with members of a community in a democratic form of government, and a legal status associated with nation-states. Conceptualizations of citizenship have changed over time in response to internal and external events such as shifts in political environments, societal understandings of multiculturalism, and increased immigration and globalization. They have also been shaped by changes in technology and the economy (JENKINS et al. 2009). Many argue that the definition of citizenship should be broadened from a national to an international scale (MYERS 2006). In the United States, however, there is little interest in moving in this direction.

At the individual level, people have different underlying beliefs about what constitutes citizenship and thus, goals for citizenship education. Research conducted to answer the question "What kind of citizen do we need to support an effective democratic society?" finds Americans hold three different but not mutually exclusive visions of citizenship: the personally responsible citizen, the participatory citizen, and the justice-oriented citizen (WESTHEIMER \& KAHNE 2004).

The personally responsible citizen acts conscientiously in his or her own community. Such a citizen engages in activities like paying taxes, obeying laws, volunteering to aid charitable causes, and helping out in times of community crisis. In contrast, the participatory citizen is an active participant in the civic affairs and social life of communities at different scales of involvement - local, national, and even international. Americans holding this view of citizenship believe that a good citizen works actively within established systems and structures to solve societal problems, to support democracy, and thus, to improve society. Such citizens are motivated to "fight the good fight" whatever it is.

The third vision of citizenship, that of the good citizen as justice-oriented, is the least common conceptualization. The justice-oriented citizen calls attention to matters of right and wrong, and works to pursue issues of social justice. The justice-oriented citizen is more cerebral than visceral and seeks to analyze and understand social movements and the connections between political, economic, and social forces in order to effect systemic change by improving society. The vision of the personally responsible citizen deflects attention 
away from the kinds of questions a justice-oriented citizen might ask about, for example, corporate responsibility. Both the justice-oriented and participatory citizens are active in civic affairs, but the emphasis on social problems and critical analysis of root causes epitomizes the justice-oriented citizen.

To summarize, a participatory citizen would organize a neighborhood recycling scheme, a personally responsible citizen would contribute recyclable goods, and the justice-oriented citizen would question why society recycles and reuses so little and act to solve the root causes of resource misuse. These ideas are summarized in Table 1.

Table 1: Types of Citizens in the United States (after WeSTHEIMER \& KAHNE 2004)

\begin{tabular}{|c|c|c|c|}
\hline & $\begin{array}{l}\text { Personally Responsible } \\
\text { Citizen }\end{array}$ & $\begin{array}{l}\text { Participatory } \\
\text { Citizen }\end{array}$ & $\begin{array}{l}\text { Justice Oriented } \\
\text { Citizen }\end{array}$ \\
\hline \multirow[t]{2}{*}{ Characteristics } & $\begin{array}{l}\text { Acts responsibly in the } \\
\text { community by paying } \\
\text { taxes, recycling, volun- } \\
\text { teering. }\end{array}$ & $\begin{array}{l}\text { Organizes and partici- } \\
\text { pates actively in com- } \\
\text { munity organizations and } \\
\text { improvement efforts. }\end{array}$ & $\begin{array}{l}\text { Critically analyzes } \\
\text { social, political, econom- } \\
\text { ic issues to discern root } \\
\text { causes and to establish } \\
\text { social justice for all. }\end{array}$ \\
\hline & $\begin{array}{l}\text { Holds positive personal } \\
\text { attributes such as integri- } \\
\text { ty and honesty. }\end{array}$ & $\begin{array}{l}\text { Knows how to organize } \\
\text { and effect change within } \\
\text { organizations. }\end{array}$ & $\begin{array}{l}\text { Knows about social } \\
\text { movements and how to } \\
\text { effect systemic change. }\end{array}$ \\
\hline Differentiation of Role & $\begin{array}{l}\text { Contributes recyclable } \\
\text { goods. }\end{array}$ & $\begin{array}{l}\text { Organizes a neighbor- } \\
\text { hood recycling scheme. }\end{array}$ & $\begin{array}{l}\text { Questions society's role } \\
\text { in resource misuse and } \\
\text { waste. }\end{array}$ \\
\hline Work Role & For society & In society & About society \\
\hline $\begin{array}{l}\text { Contribution to the } \\
\text { Functioning of a Repre- } \\
\text { sentative Democracy }\end{array}$ & $\begin{array}{l}\text { Necessary but not suffi- } \\
\text { cient. }\end{array}$ & Necessary. & Necessary. \\
\hline
\end{tabular}

Consequently, BENNETT et al. (2009) focused on new citizenship styles evolving in online and offline environments. They identified two paradigms of citizenship: the dutiful citizen and the actualizing citizen. The dutiful citizen joins social organizations, participates actively in political movements, stays informed through the news media, and votes. The actualizing citizen, in contrast, while not participating in traditional citizenship activities like voting or writing to his or her representative, is engaged in social activism and focuses on what has been termed lifestyle politics such as political consumerism, social activism, and concern with social issues like gay marriage and animal rights.

The learning styles of each are different and more young adults are actualizing citizens, the result of growing up in an information-rich culture based on digital media and hyper-social networking. These ideas are summarized in Table 2 . The two competing conceptualizations are a challenge to combine, but both provide worthwhile and useful perspectives. Dutiful citizens are personally responsible and participatory; actualizing citizens are more focused on lifestyle issues related to justice. 
Table 2: Citizen Identity and Learning Styles (after BENNETT et al. 2009)

\begin{tabular}{|c|c|}
\hline Characteristics of an Actualizing Citizen & Characteristics of a Dutiful Citizen \\
\hline Weak commitment to participate in government. & Strong call to duty to participate in government. \\
\hline Focus on lifestyle politics. & Voting is the core democratic act. \\
\hline $\begin{array}{l}\text { Mistrust of media and politicians; does not follow } \\
\text { politics in the news. }\end{array}$ & $\begin{array}{l}\text { Trust in media and politicians; informed about issues; } \\
\text { follows the news. }\end{array}$ \\
\hline Joins loose networks for social action. & $\begin{array}{l}\text { Joins social organizations, interest groups, political } \\
\text { parties }\end{array}$ \\
\hline $\begin{array}{l}\text { Communicates through social media, e.g., Twitter, } \\
\text { Facebook, email. }\end{array}$ & Communicates via mass media \\
\hline Civic Learning Styles & Civic Learning Styles \\
\hline $\begin{array}{l}\text { Interactive, event-based, peer-to-peer networked } \\
\text { information sharing }\end{array}$ & $\begin{array}{l}\text { Authoritative, text-based, knowledge transmitted to } \\
\text { individuals }\end{array}$ \\
\hline Participatory media creation & Passive media consumption \\
\hline $\begin{array}{l}\text { Preference for democratic environments, learners } \\
\text { creating content }\end{array}$ & Knowledge and skills assessed by external standards \\
\hline
\end{tabular}

How these types of citizens use geospatial technologies and social media will vary, as will the education programs aimed at developing each type. Programs and curricula with the aim of producing personally responsible, dutiful citizens emphasize the development of character traits such as honesty, integrity, hard work, and self-reliance. Such programs promote student volunteer and service-learning activities so students learn to work for society. Education programs designed to prepare participatory (but dutiful) citizens emphasize understanding how organizations such as governments and charities work and providing students with practice in planning and participating in organized "good works." Students learn to work in society. Justice-oriented, actualizing educational programs, in turn, teach students about social movements and strategies to change the system rather than encouraging students to volunteer or do good works. Actualizing programs prepare students to think critically about society.

The two visions of citizenship aim to develop different types of citizen and, thus, use different educational means to accomplish their goals. It follows that educators and others concerned with creating a citizenry in a democracy like the United States should be aware of these competing views and means. Most citizenship education programs emphasize personal responsibility, particularly the components known as character education and service learning, while ignoring the other two visions. In fact, citizenship in the current conservative political climate is limited and focused almost exclusively on "character education." This entails "education" in which young people "learn" core values such as honesty, integrity, loyalty, obedience, and responsibility for one's action, not civic engagement. Although these traits are admirable, they are not attributes or skills which will necessarily enable an individual to participate in a representative democracy like the United States. Participatory citizenship and justice-oriented citizenship are essential to a functioning democracy. An artful blend of dutiful and actualizing individuals is needed to prepare citizens skilled in all dimensions of civics. The key question for geography educators, however, is what role geography and geospatial technologies can play in any of these conceptualizations of citizenship. 


\section{Geography and Citizenship Education}

Geography has historically played a role in citizenship education in the United States (STOLTMAN 1990). Early in the 20th century, geography, as part of the social studies, served citizenship; it demonstrated, "the interdependence of men while it show[ed] their common dependence on nature" (COMMISSION ON THE REORGANIZATION OF SECONDARY EDUCATION 1918). In following decades, geography contributed to the development of citizenship by helping students understand local, national, and global environmental and civic issues and by providing a geographic context for historical events. Topics and instructional methods adapted to meet the needs of a changing society. By providing knowledge about people, places, environments and related political, economic, and social issues, geography assisted in the preparation of justice-oriented citizens. Nevertheless, young Americans' ignorance of critical world issues and lack of participation in global affairs have often been blamed on poor geography education (DAVIS 2002).

The National Geography Standards: Geography for Life 1994 and its revision in 2012 provided a rationale for geography's inclusion in the curriculum stating, "With a strong grasp of geography, people are better equipped to solve issues at not only the local level but also the global level." (DOWNS \& HEFFRON 2012, 7). The Standards squarely placed geography in a new position: preparing participatory citizens. A report on the status of geography in the United States, A Road Map for Geography Education in the 21st Century (2013) argues the importance of geography education is first and foremost citizenship education:

"K-12 geography education is critical preparation for civic life and careers in the 21 st century [...] [I]n our democratic society, we all participate in societal decision making about public health, social welfare, environmental protection, and international affairs [...] [G] eography education helps prepare people for these tasks" (BEDNARZ et al. 2013, 17).

Yet another argument for the role of geography in citizenship preparation is the emancipatory role of mapping in young peoples' lives and the way it affects their political formation (MITCHELL \& ELWOOD 2012). One of the results of a year-long exploratory mapping project with children was the finding that, "the actual process of talking, writing, and mapping freely together about spatial and emotional encounters - with adults who were not parents or teachers - gave them a rare opportunity to publically articulate themselves in relation to a wider world" (797).

The emphasis on skills for civic participation has led to the development of a number of geography-based lessons in which students role-play to practice and to learn civic participation. Geographers have been quick to adopt service learning, a growing aspect of citizenship education in the United States. Defined as community service integrated into curricula, a number of examples in which students have served their community through GIS-based projects exist (DEMSKI 2011). These projects typically support a participatory vision of citizenship by encouraging students to put into practice the knowledge and ideas learned in geography, helping to solve real community problems alongside other community members. The explosion of volunteered geographic information (VGI), crowd-sourced data shared across the internet by individual citizens is a social practice with enormous implications for the development of both dutiful and actualizing citizens (ELWOOD et al.2012). The exciting work of the Spacit project in Europe and its rich conceptualization of spatial citi- 
zenship (GRYL \& JEKEL 2012) offers many lessons for geographers with interests in citizenship in the United States.

In conclusion, geography has played a role in serving visions of citizenship education in the United States and is now involved in developing personally responsible citizens through service learning. While valuable, these strategies do not necessarily involve geography educators in doing geography or developing in students the skills and perspectives mentioned in the Geography Standards. Geography educators need a new way to contribute to citizenship education in a fashion that capitalizes on the strengths of the discipline and its core spatial and ecological perspectives. We suggest that geospatial technologies and enhanced spatial thinking, in the context of web-based CyberGIS, a synthesis of cyberinfrastructure, geographic information science, spatial analysis, and spatial modeling (WANG 2010), can play an important role in citizenship education. In the next section we examine a few venues to illustrate the ways that dutiful, actualizing, participatory, and justice-oriented citizens can be developed. These venues fall into three categories: interactive mapping sites; volunteered geographic information initiatives; and citizen science projects.

\section{A New Role for Geography: Maps and Spatial Analysis}

\subsection{Interactive Mapping Sites}

As we complete this paper, the homicide of a young African-American man in Baltimore, Maryland, and the catastrophic earthquake in Nepal have provided a number of examples of ways that maps, social media, spatial analysis, and geography can shape the development of citizenship and political identity. The demonstrations in Baltimore, peaceful at first, were organized through social media, primarily by high school students, aged 14 to 18 . The ensuing confrontation with police garnered national attention. But the story of the poverty of Baltimore and the underlying economic, social, political and structural factors contributing to this societal crisis are best told through maps. A number of U.S. newspapers and media providers, notably the Washington Post, the New York Times, and The Atlantic Magazine's CityLab use powerful interactive maps to explore a range of spatial issues. Some examples are provided in Tab.3.

In the hands of artful geography and social studies teachers, these CyberGIS resources could encourage young adults to examine significant political issues often focused on social justice and to develop knowledge, empathy, and key citizenship practices. In fact, young adults consult such resources routinely and rely on them for news, opinions, and analysis. The development of online, interactive resources by newspapers and magazines is testament to the growing importance of these information sources, especially to the younger generation.

\subsection{VGI Initiatives}

In Nepal the efforts of citizen cartographers are contributing VGI to serve humanitarian efforts using OpenStreetMap (see Tab.3 for link) Disaster relief has become a shared experience with individuals thousands of miles away able to help with mapping. Mobile phone applications like SeeClickFix allow citizens to report non-emergency neighborhood issues 
like trash accumulation or broken water pipes to local government. Once an issue is resolved, contributors and others in the area receive an update. Such a form of local community activism may attract young adults who prefer loose social networks, individual as opposed to collective actions, and who are heavy mobile phone users. A third example of VGI which contributes to peoples' environmental awareness and can lead to both participatory and justice oriented action are roadkill sites. These are online data collection points where people report animals hit and killed by cars. California and Maine are two states with active websites collecting information on animal migrations through this mechanism. It is precisely the kind of project that geographers can engage in to interest students in threatened and endangered places and environments. The ability to access information and visualize conditions in real time can make young people cognizant of issues and conditions, the precursor to the formation of political identity and action.

\subsection{Citizen Science Projects}

In many cases it is difficult to distinguish between VGI initiatives and Citizen Science projects; in both instances individuals are engaged in collecting data and sharing it using web-based services. However, Citizen Science projects tend to focus more on environmental issues and concerns, recruit amateurs to work with professional scientists, and emphasize doing science (see Tab. 3 for examples including the Audobon Society's very popular Christmas Bird Count and a collection of projects from Scientific American magazine). The Citizen Science movement has been framed as a way to excite the general public about science and to demystify the processes of "discovery." The Citizen Science project most close to geography and geography education is FieldScope, sponsored by the National Geographic Society. FieldScope's tag line is online mapping for Citizen Science investigation, and that is what it offers through projects that range from understanding water quality issues in a heavily urbanized watershed, Chesapeake Bay, to monitoring the arrival of spring in order to explore climate change. FieldScope incorporates a mobile phone application linked to a website and allows individuals, primarily students aged 12 to 16 , to collect and contribute data that can be mapped. Some of the lessons designed for use by educators explicitly require students to make decisions and recommend policies based on their analyses of environmental data. These young adults are participating in a group endeavor to improve their community; they are developing the critical and analytical skills essential to a justice orientation; and they are contributing to the solution of community problems. So while Citizen Science projects are designed primarily to encourage young people to do science, the opportunity to address broader, systemic and structural issues from a justice perspective is present. 
Table 3: Types of Geospatial Technologies That Support Citizenship Development

\begin{tabular}{|c|c|c|}
\hline Type & Examples & Description \\
\hline \multirow{5}{*}{$\begin{array}{l}\text { Interactive } \\
\text { Mapping } \\
\text { Sites }\end{array}$} & http://tinyurl.com/nzrvmwl & $\begin{array}{l}\text { Development of Baltimore's economic, } \\
\text { racial, and social geographies. }\end{array}$ \\
\hline & http://tinyurl.com/leh8pzj & $\begin{array}{l}\text { Damage in Gaza viewed through comparison } \\
\text { of remotely sensed images. }\end{array}$ \\
\hline & http://tinyurl.com/loqp2wc & Spatial patterns of inequalities in Baltimore. \\
\hline & $\begin{array}{l}\text { http://www.coopercenter.org/demographics/ } \\
\text { Racial-Dot-Map }\end{array}$ & $\begin{array}{l}\text { An interactive, scalable map of race in the } \\
\text { United States. }\end{array}$ \\
\hline & http://www.citylab.com/posts/maps/ : & $\begin{array}{l}\text { CityLab is a curated collection of interactive } \\
\text { maps across a range of topics, serious to fun. }\end{array}$ \\
\hline \multirow[t]{3}{*}{ VGI Sites } & $\begin{array}{l}\text { http://www.citylab.com/weather/2015/04/ano } \\
\text { ther-way-to-help-humanitarian-efforts-in- } \\
\text { nepal-start-mapping/391523/ }\end{array}$ & $\begin{array}{l}\text { OpenStreetMap of Katmandu, Nepal de- } \\
\text { signed to assist in relief efforts. }\end{array}$ \\
\hline & http://seeclickfix.com & $\begin{array}{l}\text { SeeClickFix is a local voluntary application } \\
\text { to register comments about community } \\
\text { issues. }\end{array}$ \\
\hline & $\begin{array}{l}\text { http://www.wildlifecrossing.net/california/ } \\
\text { http://www.wildlifecrossing.net/maine/ }\end{array}$ & $\begin{array}{l}\text { Roadkill Observation Systems to monitor and } \\
\text { record wildlife deaths along roadways. }\end{array}$ \\
\hline \multirow[t]{3}{*}{$\begin{array}{l}\text { Citizen } \\
\text { Science }\end{array}$} & $\begin{array}{l}\text { http://www.audubon.org/conservation/scienc } \\
\text { e/christmas-bird-count }\end{array}$ & $\begin{array}{l}\text { The Christmas Bird Count asks people to } \\
\text { count birds at a specific time of the year each } \\
\text { year and share results. }\end{array}$ \\
\hline & $\begin{array}{l}\text { http://www.scientificamerican.com/citizen- } \\
\text { science/ }\end{array}$ & $\begin{array}{l}\text { A collection of Citizen Science projects } \\
\text { organized by a popular science journal. }\end{array}$ \\
\hline & $\begin{array}{l}\text { http://education.nationalgeographic.com/edu } \\
\text { cation/programs/fieldscope/?ar_a=1 }\end{array}$ & $\begin{array}{l}\text { FieldScope: An mapping application and } \\
\text { lessons designed to help young people make } \\
\text { informed decisions. }\end{array}$ \\
\hline
\end{tabular}

\section{$6 \quad$ Next Steps}

Research on the effectiveness of various citizenship education programs in the United States indicates mixed success (Westheimer \& KAHNE 2004, BenNETT et al. 2009). Programs that emphasize participation do not necessarily develop student abilities to analyze and think critically about the root causes of civic problems. At the same time, educational initiatives aimed at character development do not create students interested in or possessing the skills to participate in civic life.

Geography educators should be engaged in the development of well-rounded citizens with the personal characteristics, skills, and habits of mind required for citizenship in a democracy. While engaging in geospatial projects is not the only way that geography can participate more fully in citizenship education, we believe it is an effective and appropriate way for students to use the core spatial and ecological perspectives of geography and to contribute to their community, nation, and world. To this end we recommend that geographers embrace the ideals of citizenship education and marry them with our skills in dynamic representations. Finally, we conclude with a call for careful and focused research to uncover the effects of these different types of geospatial technologies on young adults. What works, why, how, for whom, under what circumstances, and to what ends? 


\section{References}

BeDnARZ, S. W. \& ACHESON, G. A. (2003), Learning to be a citizen in post 9/11 United States: What role for geography? Proceedings of the Commission on Geographic Education, Geography and Citizenship Education. Institute of Education, University of London.

BEDNARZ, R. S. \& BEDNARZ, S. W. (2008), The importance of spatial thinking in an uncertain world. In: SUI, D. Z. \& CUTTER S. L. (Eds.), Geospatial technologies and homeland security. Springer, 315-330.

Bednarz, S. W., HefFron, S. M., \& Huynh, N. T. (2013), A roadmap for $21^{\text {st }}$ century geography education: geography education research. Association of American Geographers, Washington D.C.

BenNetT, W. L., Wells, C. \& RANK, A. (2009), Young citizens and civic learning: Two paradigms of citizenship in the digital age. Citizenship Studies, 13 (2), 105-120.

COMMISSION ON THE REORGANIZATION OF SECONDARY EDUCATION (1918), Cardinal principles of secondary education. Government Printing Office, Washington, D.C.

DAVIS, M. R. (2002), Paige urges new focus on international education. Education Week November 27, 2002, 20.

DEMSKI, J. (2011), Map quests. THE Journal. http://thejournal.com/Articles/2011/09/12/Map-Quests.aspx?p=1 (1.27.2015).

Downs, R. M. (2014), Coming of age in the geospatial revolution: The geographic self redefined. Human Development, 57, 35-57.

Downs, R. M. \& HefFron, S. M. (2012), Geography for life: National geography standards. National Council for Geographic Education, Washington D.C.

Elwood, S., GoodchiLd, M. F. \& SuI, D. Z. (2012), Researching volunteered geographic information: Spatial data, geographic research, and new social practice. Annals of the Association of American Geographers, 102 (3), 571-590.

Flanagan, C. \& Levine, P. (2010), Civic engagement and the transition to adulthood. The future of children, 20 (1), 159-179.

GRYL, I. \& JEKEL, T. (2012), Re-centring geoinformation in secondary education: Toward a spatial citizenship approach. Cartographica, 47 (1), 18-28.

Jenkins, H, Clinton, K., Purushotma, Robison, A. K. \& Weigel, M. (2009), Confronting the challenges of participatory culture: media education for the $21^{\text {st }}$ century. Chicago, Il.: MacArthur Foundation.

http://mitpress.mit.edu/books/confronting-challenges-participatory-culture (4.30.2015).

KeEter, S., Zukin, C., Andolina, M \& Jenkins, K. (2002), The civic and political health of the nation: A generational portrait. http://www.civicyouth.org/research/products/Civic_Political_Health.pdf (4.30.2015).

Mitchell, K. \& ElWOOD, S. (2012), Mapping children's politics: The promise of articulation and the limits or nonrepresentational theory. Environment and Planning D: Society and Space, 30 (5), 788-804.

MYERS, J. P. (2006), Rethinking the social studies curriculum in the context of globalization: Education for global citizenship in the U.S. Theory and Research in Social Education, 34 (3), 370-394.

MurPhY, J. B. (2002), Good students and good citizens. New York Times, September 15, 2002. 
NAEP (2015), http://www.nationsreportcard.gov/hgc_2014/\#civics/achievement (4.30.2015).

PARKER, W. C. (2014), Citizenship education in the United States: Regime type, foundational issues, and classroom practice. In: NuCCI, L. P., NARVAEZ, D. \& Krettenauer, T. (Eds.), The handbook of moral and character education. Routledge, New York, 347367.

PutNAM, R. (2000), Bowling alone: The collapse and revival of American community. Simon \& Schuster, New York.

RuBIN, B. C. (2015), A time for social studies: Talking with young people about Ferguson and Staten Island. Social Education, 79 (1), 22-29.

Stoltman, J. P. (1990), Geography education for citizenship. Social Science Education Consortium, Boulder, CO.

ThORNTON, S. J. (2004), Citizenship and social studies curriculum change after 9/11. In: Woyshner, C. H., VARgas, J. \& CROCCO, M. (Eds.), Social education in the $20^{\text {th }}$ century. Peter Lang, New York, 210-220.

WANG, S. (2010), A cyberGIS framework for the synthesis of cyberinfrastructure, GIS, and spatial analysis. Annals of the Association of American Geographers, 100 (3), 535-557.

Westheimer, J. \& KAHNE, J. (2004), What kind of citizen? The politics of educating for democracy. American Educational Research Journal, 41 (2), 237-269. 